\title{
Social Darwinism and psychopathology
}

Andreas Erfurth

From $1^{\text {st }}$ International Congress on Neurobiology and Clinical Psychopharmacology and European

Psychiatric Association Conference on Treatment Guidance

Thessaloniki, Greece. 19-22 November 2009

In recent years, aspects of Darwinism have been widely discussed in psychiatry to explain the origins of mood disorders [1-3]. Authors were particularly focusing on the psychopathology of depression, while other considerations in the field of affective disorders have more broadly included the phenomena of mania [4] and temperament [5]. This paper will review aspects of Darwinism in the psychopathology of mood and its social consequences.

Published: 22 April 2010

\section{References}

1. Nesse RM: Evolution is the scientific foundation for diagnosis: psychiatry should use it. World Psychiatry 2007, 6:160-1.

2. Nesse RM, Ellsworth PC: Evolution, emotions, and emotional disorders. Am Psychol 2009, 64(2):129-39.

3. Allen NB, Badcock PB: Darwinian models of depression a review of evolutionary accounts of mood and mood disorders. Prog Neuropsychopharmacol Biol Psychiatry 2006, 30(5):815-26.

4. Koukopoulos A, Ghaemi SN: The primacy of mania: a reconsideration of mood disorders. Eur Psychiatry 2009, 24(2):125-34.

5. Akiskal KK, Akiskal HS: The theoretical underpinnings of affective temperaments: implications for evolutionary foundations of bipolar disorder and human nature. J Affect Disord 2005, 85(1-2):231-9.

Submit your next manuscript to BioMed Central and take full advantage of:

- Convenient online submission

- Thorough peer review

- No space constraints or color figure charges

- Immediate publication on acceptance

- Inclusion in PubMed, CAS, Scopus and Google Scholar

- Research which is freely available for redistribution

Submit your manuscript at www.biomedcentral.com/submit
C Biomed Central 